"The effect of enforcement intensity on illegal insider trading volume: the case of Taiwan"

\begin{tabular}{|c|c|c|}
\hline AUTHORS & \multicolumn{2}{|l|}{$\begin{array}{l}\text { Han-Ching Huang } \\
\text { Jung-Tzu Chang }\end{array}$} \\
\hline ARTICLE INFO & \multicolumn{2}{|c|}{$\begin{array}{l}\text { Han-Ching Huang and Jung-Tzu Chang (2016). The effect of enforcement } \\
\text { intensity on illegal insider trading volume: the case of Taiwan. Investment } \\
\text { Management and Financial Innovations, 13(2-1), 141-148. } \\
\text { doi:10.21511/imfi.13(2-1).2016.02 }\end{array}$} \\
\hline DOI & \multicolumn{2}{|c|}{ http://dx.doi.org/10.21511/imfi.13(2-1).2016.02 } \\
\hline RELEASED ON & \multicolumn{2}{|l|}{ Monday, 04 July 2016} \\
\hline JOURNAL & \multicolumn{2}{|c|}{ "Investment Management and Financial Innovations" } \\
\hline FOUNDER & \multicolumn{2}{|c|}{ LLC “Consulting Publishing Company "Business Perspectives” } \\
\hline \multirow{2}{*}{ NUMBER OF REFERENCES } & & $\begin{array}{l}\text { ニニ } \\
\text { ニ:- }\end{array}$ \\
\hline & NUMBER OF FIGURES & NUMBER OF TABLES \\
\hline 0 & 0 & 0 \\
\hline
\end{tabular}

(C) The author(s) 2022. This publication is an open access article. 
Han-Ching Huang (Taiwan), Jung-Tzu Chang (Taiwan)

\title{
The effect of enforcement intensity on illegal insider trading volume: the case of Taiwan
}

\begin{abstract}
In this paper, the authors examine the illegal insider trading volume and cumulative abnormal return by the relative variables of the amendment, the change of the securities price, the number of defendants, the penalty and the fine for insider who committed a crime, and the quality of concealed important information. Illegal insider trading is prohibited by the article 157-1 of Securities and Exchange Act in Taiwan. It has been amended three times to provide a sound and rigorous law and completely protect investors. The authors examine the illegal insider trading volume after the amendment to explore whether the Securities and Exchange Act is efficient enough to lower illegal insider trading. The authors find that the change of the securities price and the quality of concealed important information are the critical factors which affect the illegal insider trading volume and cumulative abnormal returns. Nevertheless, the relative variables of the amendment do not show significant effects.
\end{abstract}

Keywords: illegal insider trading volume, cumulative abnormal return, insider trading penalty.

JEL Classification: G12, G14, G38.

\section{Introduction}

The illegal inside trading has been an issue being concerned by the public. It has also been a public problem that the government is desperate to solve. Since trading fairness is affected by inside trading, most people lose properties while a few inside traders earn profit. Although inside trading is not all illegal, there are both positive and negative views for the act of legislation prohibiting insider trading, and most countries hold the position of prohibiting inside trading. Bhattacharya and Daouk (2002) indicate that 87 of 103 countries in their research legislate the law about inside trading, and there are only 38 of them which have litigation due to the inside trading. A number of economists argue whether inside trading is common or detrimental. Some hold positive views of insider trading, and consider that the unpublished information will get to the market much faster, which is more efficient to the market. For example, Milton Friedman ${ }^{1}$, the Nobel Laureates in 1976, considers that the faster speed of internal information reaching market will be more helpful than legislating the law about inside trading (Hung, 2011).

Due to the information asymmetry between insiders and ordinary investors, the investors could use nonpublic information to make profits (Meulbroek, 1992; Cornell and Sirri, 1992; Chakravarty and McConnell, 1997; Fishe and Robe, 2004).

\footnotetext{
(C) Han-Ching Huang, Jung-Tzu Chang, 2016.

Han-Ching Huang, Department of Finance, Chung Yuan Christian University, Chung Li, Taiwan.

Jung-Tzu Chang, Department of Finance, Chung Yuan Christian University, Chung Li, Taiwan.

${ }^{1}$ Milton Friedman, a Nobel laureate in economics, said in an interview on CNBC's Power Lunch on March 12, 2003:'There are many people going to jail for insider trading and I think it is a great mistake. We want more insider tradings, not less. We should provide more knowledge about deficiencies of the company to let the public aware of that."
}

Nevertheless, many studies show that the insiders do not trade a large amount of stock volume. Although a relatively large amount of stock trading may earn more returns, it is easier to be caught and be prosecuted (Frino et al., 2009). Thus, the returns of transactions and the imposition of sanctions can affect inside trading volume.

In recent years, securities management authorities in every country are dedicated to information disclosing and the amendment of relative regulations to improve the fairness of securities market trading. Guercio et al. (2013) indicate that there is a negative relationship between the volume of insider trading and the sanctions imposed by US Securities and Exchange Commission (SEC). Wang and Jan (2012) analyze the volume of insider trading of the listed companies in Taiwan, and find out the improvement owing to the amendment. There are relevant regulations about information disclosing and insider trading in Securities and Exchange Act in Taiwan. However, the concealment of insider trading enhances the difficulty to observe by outsiders. According to World Competitiveness Yearbook published by IMD business school, Taiwan is rated within 40-50 among 60 countries in the insider trading rank. The more behind the rank, the more insiders trading executed (Kuang and Chiang, 2007). The frequent illegal insider trading has sacrificed the public investors' interest and may further cause an economic panic. In this paper, we explore the possible factors to affect the illegal insider trading volume, and examine whether the legislation and amendment are efficient-preventing. Specifically, we propose humble opinion as a reference for future possible prevention policies.

We find that the change of the securities price has the positive and significant impact on the illegal insider trading volume and cumulative abnormal return. The quality of concealed important 
information also shows a positive impact on the illegal insider trading volume, but not on the cumulative abnormal returns. When the concealed important information is bad news, the stock price goes down. The insider will trade in stock market to avoid from loss. Thus, it results in abnormal trading volume and negative cumulative abnormal returns. The relative variables of the amendment do not show significant effects. It might be the number of sample is not sufficient.

Our study is organized as follows. We review the literature in Section 1. Section 2 describes the data. Methodology is explained in section 3. Section 4 discusses empirical results. Finally, we conclude.

\section{Literature review}

1.1. Illegal insider trading. Meulbroek (1992) explores illegal insider trading data from US Securities and Exchange Commission and found out the average abnormal returns of illegal insider trading day is $3 \%$. Before the stock prices declare, about half of them have increased apparently before the acquisition. Chakravarty and McConnell (1997) examine Ivan Boesky's purchases of Carnation's stock prior to Nestle's acquisition of Carnation. There is significant positive correlation between transactions and stock price changing while bid-ask spread and depth do not show impact or increase due to transactions. Furthermore, after insiders receive internal information, they are more likely to utilize margin purchasing and short selling to earn more returns. Yi (2010) examines margin purchasing, short sale, and bid-ask spread in illegal insider trading in Taiwan security market on the important information announcement. It shows that there is abnormal short selling before bad news announced, indicating negative impact on the returns of security. Also, margin purchasing and short selling will increase the bid-ask spread before information announcement.

In addition, corporation governance has been concerned by public in recent years. A superior corporation with corporation governance can help preventing insider trading from taking place. Wang (2010) finds out insider who executed illegal insider trading would possible utilize non-public information resulting from agent problem or imperfect oversight mechanisms according to following reasons: the bad news concealed by corporation, too much insiders involved in illegal insider trading, serious information asymmetry, family business, the absence of independent directors or lower independent director rate, lower corporate ownership ratio, and no payment for directors and supervisors. Hou (2013) studies the cases of prosecuted inside trading in Taiwan security market through 1988 to 2008. While the inside trading shows positive impact by the rewritten of financial statement, the frequency of chairman replacement, surplus management, and the frequency of accountant replacement. Moreover, the full-cash delivery stock implies the weak internal control of corporation and a higher possibility of insider crime.

However, despite of information advantage, the insiders do not trade a large amount of stock according to many inside trading researches. Frino et al. (2009) indicates that inside trading involves the interaction of two opposing emotions, fear and greedy. Although the more amount of stock trading, the more returns will earn; more amount of stock trading will be caught by public easily and might be prosecuted heavier penalty. The result shows that the inside trading will be executed when the expected cost of using non-public information is lower than the returns from illegal insider trading. There is a positive impact between the volume of insider trading and the returns of trading.

1.2. The result for relevant laws and regulations. Wang and Ran (2012) explore the announcement of seasoned equity offerings (SEO) by the board of directors in Taiwan listed and OTC companies. They use event study to compare the data before and after the amended Securities and Exchange Act on January 13th 2004. Whether the investors in Taiwan security market react differently due to the SEO prior to the amendment is examined in the subsequence improvement of insider trading. The result shows that less insider trading still exists after the amendment.

Guercio et al. (2013) study the impact on law enforcement strength to illegal insider trading in United States Securities and Exchange Commission (SEC), filing the illegal insider trading with as a sample case in the last decade. It shows the negative impact on the volume of insider trading and the changes of price to the precautionary measure which the SEC imposed to prevent illegal insider trading. They also find that both the volume of insider trading and the price changing in insider trading days are smaller than the result of the case in 1980s employed by Meulbroek (1992). It implies that the more precautionary measure that SEC enforces, the more illegal insider trading can be prevented. The result shows there is constraint to illegal insider trading when the SEC sets up relevant laws and regulations.

\section{Data}

Our sample consists of illegal insider trading events which are persecuted by court through 1996 to 2012 in Taiwan. The sample events are available in verdict query system of Judicial Yuan, Taiwan Economic Journal, market observation post system of Taipei 
Exchange, cnYES, udndata, and Chinatimes database. There are 96 transaction samples and 242 defendant samples which are selected in the group of 94 listed and OTC sample companies persecuted by court due to illegal insider trading.

Figure 1 illustrates the illegal insider trading time diagram. After the concealed important information appears, the insider trading period is defined from the first crime date to the time important information announced, where the insiders trade to earn abnormal returns or to avoid loss. As to external investors, they will not receive the important information till it has been fully reflected and disclosed, which has already harmed their wealth.

Important information

fully reflected

Important information appeared

Insider trading period

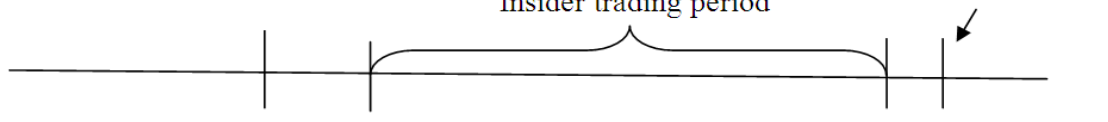

The first crime date Important information announced

Fig. 1. The illegal insider trading time diagram

We further investigate the industry and annual distribution of illegal insider trading events as Table 1 bellow. It shows most of the illegal insider trading event happened in electronics industry, which is total of 54 event sample (more than half of sample size).
We infer the rapid development of electronics industry makes itself rich in information. Through 2003 to 2006, the prosecution of electronics industry brings to a peak and reduces in following years, which might be effected by the amendment in Taiwan.

Table 1. Industry and annual distribution of illegal insider trading event

\begin{tabular}{|c|c|c|c|c|c|c|c|c|c|c|c|c|c|c|c|c|c|c|}
\hline Industry/year & $\stackrel{\circ}{\circ}$ & 嵒 & $\stackrel{\circ}{\stackrel{\circ}{9}}$ & 営 & ০ั & 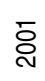 & ๙ั่ & @̊ & ঃั & 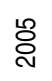 & \& & ڤ్ & 怘 & ঃ্̀ & 울 & $\bar{c}$ & ָั้ & 営 \\
\hline Electronics & & 1 & & & & 1 & 3 & 6 & 6 & 6 & 16 & 4 & 5 & 3 & 1 & & 2 & 54 \\
\hline $\begin{array}{l}\text { Building materials and } \\
\text { construction }\end{array}$ & & & 1 & 1 & & 2 & 2 & & & 2 & & & 1 & & & & & 9 \\
\hline Finance and insurance & & & & 1 & & & 1 & & & 2 & 1 & 1 & & & & & & 6 \\
\hline Textile fibers & & & 1 & & 1 & 1 & 1 & & & & & & & & & & & 4 \\
\hline Others & 1 & 1 & 3 & 1 & 1 & 1 & 1 & 1 & 1 & 1 & 1 & 5 & 1 & & & 1 & & 20 \\
\hline Total & 1 & 2 & 5 & 3 & 2 & 5 & 8 & 7 & 7 & 11 & 18 & 10 & 7 & 3 & 1 & 1 & 2 & 93 \\
\hline
\end{tabular}

Table 2 presents the statistics of illegal insider trading company, transaction, quality of important information and defendants. The percentage of the company involved in illegal insider trading is the highest in 2006. However, the number of prosecuted companies should be lower than the number of companies in which insider trading take place. In addition, we group the illegal insider trading into "good news" and "bad news" ". There are 37 good news and 61 bad news in the survey, which indicates that the insider have stronger motivation to trade before the announcement to avoid loss when the internal important information is bad news. In the contrary, the unformed external investors' interest will be sacrificed. Furthermore, we find out the illegal insider trading event is diversity, which is showed as Table 3. The most content of illegal insider trading is bad news, such as financial loss, lowering the financial forecast, financial crisis. Those events lead the stock price to decrease, which brings out the motivation of denying the up-coming crisis for company and the motivation of escaping from loss for insiders. Thus, we infer that the worse operating or financial conditions are in a company, the more possibility of illegal insider trading exists.

Table 2. Statistics of illegal insider trading company, transaction, quality of important information, and defendants

\begin{tabular}{|c|c|c|c|c|c|c|c|}
\hline \multirow{2}{*}{ Year } & \multirow{2}{*}{$\begin{array}{c}\text { Number of listed } \\
\text { and OTC } \\
\end{array}$} & \multirow{2}{*}{$\begin{array}{c}\text { Number of illegal insider } \\
\text { trading involved company }\end{array}$} & $\begin{array}{c}\text { Percentage of illegal } \\
\text { insider trading } \\
\text { transaction }\end{array}$ & $\begin{array}{c}\text { Number of } \\
\text { illegal insider } \\
\text { trading }\end{array}$ & \multicolumn{2}{|c|}{$\begin{array}{c}\text { Quality of important } \\
\text { information }\end{array}$} & \multirow{2}{*}{$\begin{array}{c}\text { Number of } \\
\text { defendants }\end{array}$} \\
\cline { 5 - 7 } & & 1 & 0.23 & 1 & 0 & 1 & 1 \\
\hline 1996 & 431 & 2 & 0.39 & 2 & 2 & 0 & 11 \\
\hline 1997 & 510 & 5 & 0.80 & 5 & 2 & 3 & 8 \\
\hline 1998 & 623 & 3 & 0.41 & 3 & 1 & 2 & 5 \\
\hline 1999 & 737 & 4 & 0.48 & 4 & 1 & 3 & 11 \\
\hline 2000 & 832 & & & & & & \\
\hline
\end{tabular}

\footnotetext{
${ }^{2}$ In this study, we group the illegal insider trading into good news and bad news, depending on the subsequence reaction to the stock price after the announcement. If the stock price increases, the important information is classified to good news and vice versa.
} 
Table 2 (cont.). Statistics of illegal insider trading company, transaction, quality of important information, and defendants

\begin{tabular}{|c|c|c|c|c|c|c|c|}
\hline \multirow{2}{*}{ Year } & \multirow{2}{*}{$\begin{array}{c}\text { Number of listed } \\
\text { and OTC } \\
\text { company }\end{array}$} & \multirow{2}{*}{$\begin{array}{c}\text { Number of illegal insider } \\
\text { trading involved company }\end{array}$} & $\begin{array}{c}\text { Percentage of illegal } \\
\text { insider trading } \\
\text { transaction }\end{array}$ & \multirow{2}{*}{$\begin{array}{c}\text { Number of } \\
\text { illegal insider } \\
\text { trading }\end{array}$} & \multicolumn{2}{|c|}{$\begin{array}{c}\text { Quality of important } \\
\text { information }\end{array}$} & \multirow{2}{*}{$\begin{array}{c}\text { Number of } \\
\text { defendants }\end{array}$} \\
\cline { 6 - 8 } & & & Good news & Bad news & \\
\hline 2001 & 945 & 5 & 0.53 & 6 & 1 & 5 & 9 \\
\hline 2002 & 1129 & 9 & 0.80 & 9 & 0 & 9 & 15 \\
\hline 2003 & 1184 & 4 & 0.34 & 4 & 0 & 4 & 10 \\
\hline 2004 & 1211 & 7 & 0.58 & 8 & 2 & 8 & 18 \\
\hline 2005 & 1236 & 12 & 0.97 & 12 & 7 & 5 & 26 \\
\hline 2006 & 1268 & 18 & 1.42 & 18 & 9 & 9 & 65 \\
\hline 2007 & 1310 & 10 & 0.76 & 10 & 4 & 6 & 16 \\
\hline 2008 & 1341 & 7 & 0.52 & 7 & 2 & 5 & 22 \\
\hline 2009 & 1395 & 3 & 0.22 & 3 & 2 & 1 & 15 \\
\hline 2010 & 1428 & 1 & 0.07 & 1 & 1 & 0 & 1 \\
\hline 2011 & 1455 & 1 & 0.07 & 1 & 1 & 0 & 2 \\
\hline 2012 & 1458 & 2 & 0.14 & 2 & 2 & 0 & 7 \\
\hline Total & & 94 & & 96 & 37 & 61 & 242 \\
\hline
\end{tabular}

\section{Methodology}

We regard the 200 trading day before the first crime day to the first crime day as the estimation period, and analyze the event period ${ }^{3}$ from the first crime date to the $10^{\text {th }}$ trading day after it. In addition, we use the ratio of the average trading volume of insider trading period and the average trading volume of estimation period to compute the abnormal trading volume of illegal insider trading event, illustrated as Figure 2.

Table 3. Classification of illegal insider trading content

\begin{tabular}{|l|c|c|}
\hline \multicolumn{1}{|c|}{ Content } & Frequency & Percentage $\%$ \\
\hline Financial losses & 13 & 13.27 \\
\hline Lowering the financial forecast & 19 & 19.39 \\
\hline Financial crisis & 15 & 15.31 \\
\hline Consolidation & 14 & 14.29 \\
\hline Disposal of assets & 6 & 6.12 \\
\hline Fund-raising & 5 & 5.10 \\
\hline Restructuring & 4 & 4.08 \\
\hline Others & 22 & 22.45 \\
\hline Total & 98 & 100 \\
\hline
\end{tabular}

Notes: Other illegal insider trading total of 22 included 3 asset reduction, 3 judicial crisis, 2 joint venture, 2 implement treasury shares, 2 lifting of the contract, 2 acquisition shareholdings, 2 sale of the plant, 1 higher the financial forecast, 1 transfer shareholdings, 1 asset impairments, 1 signing contract, 1 reinvestment.

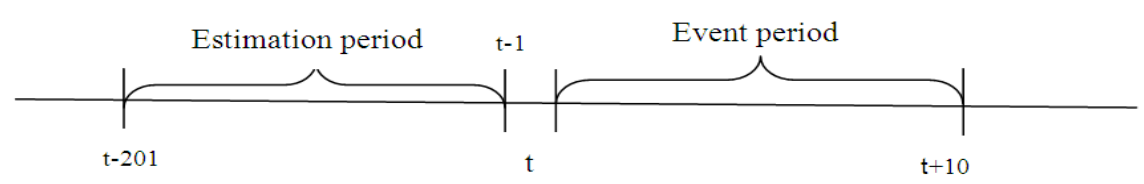

The first crime date

Fig. 2. The illegal insider trading event period and estimation period

To examine the impact on the illegal insider trading volume, the change of the securities price, the number of defendants, the penalty and the fine for insider who committed a crime, the quality of concealed important information, we run the regression model as follow:

\footnotetext{
${ }^{3}$ In most situations, the stock price could not fully reflect as information announced. It should be reasonable and accurate to define the event period from the first crime date to the day price reflected completely which is not entire collected. Thus, we regard the first crime date to the $10^{\text {th }}$ trading day after it as event period in this study.
}

$\ln \left(\right.$ Abnormal volume $\left._{i}\right)=\alpha+\beta_{1} \ln \left(\mid\right.$ Price change $\left._{i} \mid\right)+$

$+\beta_{2}$ Insider $_{i}+\beta_{3}$ Fine $_{i}+\beta_{4}$ Penalty $_{i}+\beta_{5}$ News $_{i}+\varepsilon_{i}$,

where Abnormal volume $i$ is the average trading volume from crime event date $i$ to disclose day divided by the daily average trading volume of the stock in estimated period. Price change ${ }_{i}$ is the stock price of the 10 day after event i divided by the stock price before the first crime date. Insider $i$ is the number of defendants prosecuted during event $i$. If the defendant of event $i$ is fined, Fine $e_{i}$ is 1,0 
otherwise. If the defendant is sentenced to a penalty, Penalty $_{i}$ is 1,0 otherwise. If the concealed important information of event i company is good news, News $_{i}$ is 1, 0 otherwise.

We use market-adjustment model to calculate abnormal returns (AR). The first crime date is defined as day 0 , and $t$ as $t$ days after the first crime date. The model is presented as follows:

$$
\begin{aligned}
& A R_{j t}=R_{j t}-R_{m t}, \\
& C A R_{i}=\sum_{t=b}^{e} A R_{j t},
\end{aligned}
$$

where $R_{j t}$ is actual returns rate of sample stock $j$ on day $t$ during the event period; $R_{m t}$ is market return of the value weighted index (we use TAIEX as a proxy) on day $t ; A R_{j t}$ is abnormal returns rate of sample stock $j$ on day $t$ during the event period; Cumulative abnormal return $\left(C A R_{i}\right)$ is the cumulative abnormal returns rate of sample stock $i$ in the event window; $b$ is the staring date of event window; $e$ is ending date of event window.

We regress CAR on the above independent variables. The regression model (2) is as follow:

$$
\begin{aligned}
& \text { CAR }_{i}=\alpha+\beta_{1} \ln \left(\mid \text { Price change }_{i} \mid\right)+ \\
& +\beta_{2} \text { Insider }_{i}+\beta_{3} \text { Fine }_{i}+\beta_{4} \text { Penalty }_{i}+\beta_{5} \text { News }_{i}+\varepsilon_{i} .
\end{aligned}
$$

Moreover, we examine whether the amended laws and regulations are efficient enough to prevent illegal insider trading. We divide the sample into 4 intervals: The first interval, January 1, 1996 to February 6, 2002, is the period before the first amendment of relevant laws and regulations. The second interval, February 6, 2002 to January 11, 2006 , is the period between the first and second amendment. The third interval, January 11, 2006 to June 2, 2010, is the period between the second and third amendment. The last interval is June 2, 2010 to December 31, 2012. We examine whether the illegal insider trading volume decreases when the laws and regulations are amended. Then, we add the dummy variables, $L a w_{1}, L a w_{2}, L a w_{3}$ in the previous regression model, presented as the following (3):

$$
\begin{aligned}
& \ln \left(\text { Abnormal volume }_{i}\right)=\alpha+\beta_{1} \ln \left(\mid \text { Price change }_{i}\right)+ \\
& +\beta_{2} \text { Insider }_{i}+\beta_{3} \text { Fine }_{i}+\beta_{4} \text { Penalty }_{i}+\beta_{5} \text { News }_{i}+\beta_{6} \text { Law }_{1}+ \\
& +\beta_{7} \text { Law }_{2}+\beta_{8} \text { Law }_{3}+\varepsilon_{i} .
\end{aligned}
$$

where if event $i$ occurs in the period between the first amendment in 2002 and second amendment in 2006, $L a w_{1}$ is 1,0 otherwise. If event $i$ occurs in the period between second amendment in 2006 and the third amendment in 2010, $\mathrm{Law}_{2}$ is 1,0 otherwise. If event $\mathrm{i}$ occurs after the third amendment in 2010 $L a w_{3}$ is 1,0 otherwise.

Likewise, we regress $C A R$ on the above independent variables. The regression model (4) is as follow:

$$
\begin{aligned}
& \text { CAR }_{i}=\alpha+\beta_{1} \ln \left(\mid \text { Price change }_{i} \mid\right)+ \\
& +\beta_{2} \text { Insider }_{i}+\beta_{3} \text { Fine }_{i}+\beta_{4} \text { Penalty }_{i}+\beta_{5} \text { Nens }_{i}+\beta_{6} \text { Law }_{1}+ \\
& +\beta_{7} \text { Law }_{2}+\beta_{8} \text { Law }_{3}+\varepsilon_{i} .
\end{aligned}
$$

\section{Empirical results}

4.1. Sample descriptive statistics. Table 4 shows the descriptive statistics of each variable. CAR with negative mean gets bigger when the range of period is more number of days. As for independent variables, the mean of the change of price is negative, indicating that the illegal insider trading makes the stock price down; most of the concealing information is bad news.

Table 4. The descriptive statistics of each variable in illegal insider samples

\begin{tabular}{|l|c|c|c|c|c|}
\hline \multicolumn{1}{|c|}{ Dependent variables } & Mean & Median & Maximum & Minimum & Standard deviation \\
\hline Abnormal volume & 0.565633 & 0.529145 & 3.235142 & -6.8564 & 1.350081 \\
\hline CAR $(0,+10)$ & -11.1617 & -10.2612 & 64.0362 & -147.465 & 37.41267 \\
\hline Independent variables & Mean & Median & Maximum & Minimum & Standard deviation \\
\hline Change of price & -0.2042 & -0.09536 & 0.967459 & -1.32803 & 0.461138 \\
\hline Number of defendants & 2.266667 & 2 & 8 & 1 & 1.376149 \\
\hline Fine & 0.333333 & 0 & 1 & 0 & 0.475383 \\
\hline Penalty & 0.566667 & 1 & 1 & 0 & 0.499717 \\
\hline Good/bad news & 0.65 & 1 & 1 & 0 & 0.480995 \\
\hline Law $_{1}$ & 0.433333 & 0 & 1 & 0 & 0.499717 \\
\hline Law $_{2}$ & 0.383333 & 0 & 1 & 0 & 0.490301 \\
\hline Law $_{3}$ & 0.05 & 0 & 1 & 0 & 0.219784 \\
\hline
\end{tabular}

Notes: There are total 98 illegal insider trading events sued by prosecutor in raw data. Nonetheless, the collection of variable is not complete, including 3 cases of the first crime date unknown, 2 media reveal date unknown, 23 incomplete stock price information, and 10 incomplete trading volumes in estimate period. The number of effective sample is 60 when we take Abnormal volume as dependent variable and it is 51 due to the lack of data in Taiwan Economic Journal database when we take CAR as dependent variable. 
The average number of defendants in illegal insider trading event is 2 and there is a case up to 8 defendants. More than half of the event is sentenced penalty whereas only one third of the event is fined. Furthermore, the frequency of crime is decreasing after each amendment.

4.2. The effect of variables to illegal execution of insider trading. In Table 5, we separately regress cumulative abnormal returns on single independent variable in models 1 to 8 . Under the single variable influence, the change of the securities price, the number of defendants, the Penalty dummy, the Fine dummy, quality of concealed important information, and the $L a w_{1}$ dummy are positive related to abnormal trading volume. Specifically, the coefficient of change of the securities price and the fine dummy are significantly positive at 5\% level. However, $L a w_{2}$ dummy and $L a w_{3}$ dummy are negatively related to abnormal trading volume.

In model 9, we regress abnormal insider trading volume on all the variables except Law dummies. It indicates that the abnormal trading volumes are positively related to the change of the securities price, the number of defendants, the penalty dummy, and the quality of concealed important information. Specifically, the coefficients of the change of the securities price and the quality of concealed important information are significantly positive at $1 \%$ level. In contrast, the coefficient of the fine dummy is negative and insignificant.

In model 10, we add the Law dummies in model 9 to examine whether the variable of relevant laws and regulations has significant impact on abnormal insider trading volume. The coefficient of change of the securities price and the quality of concealed important information are significantly positive at $1 \%$ level and the coefficient of the penalty dummy is significantly positive at 5\% level. Nevertheless, the Law dummies are negative and insignificant, implying that the relevant laws and regulations have negative and insignificant impact on abnormal insider trading volume.

Table 5. The effect on abnormal trading volume

\begin{tabular}{|c|c|c|c|c|c|c|c|c|}
\hline & $\begin{array}{c}\text { Change of } \\
\text { price }\end{array}$ & $\begin{array}{l}\text { Number of } \\
\text { defendants }\end{array}$ & Fine & Penalty & $\begin{array}{c}\text { Good/bad } \\
\text { news }\end{array}$ & $L_{a} w_{1}$ & $\mathrm{Law}_{2}$ & $\mathrm{Law}_{3}$ \\
\hline Model 1-8 & $\begin{array}{l}0.87^{\star *} \\
(0.02)\end{array}$ & $\begin{array}{c}0.11 \\
(0.41) \\
\end{array}$ & $\begin{array}{c}0.48 \\
(0.20) \\
\end{array}$ & $\begin{array}{l}0.74^{\star *} \\
(0.03)\end{array}$ & $\begin{array}{c}0.12 \\
(0.74) \\
\end{array}$ & $\begin{array}{c}0.21 \\
(0.56) \\
\end{array}$ & $\begin{array}{l}-0.06 \\
(0.86) \\
\end{array}$ & $\begin{array}{l}-0.97 \\
(0.23) \\
\end{array}$ \\
\hline Model 9 & $\begin{array}{l}1.74^{\star \star \star} \\
(0.00)\end{array}$ & $\begin{array}{c}0.03 \\
(0.82)\end{array}$ & $\begin{array}{l}-0.10 \\
(0.82)\end{array}$ & $\begin{array}{l}0.91^{\star \star} \\
(0.03)\end{array}$ & $\begin{array}{l}1.50^{\star \star \star *} \\
(0.00)\end{array}$ & & & \\
\hline Model 10 & $\begin{array}{l}1.94^{* \star *} \\
(0.00)\end{array}$ & $\begin{array}{c}0.06 \\
(0.59)\end{array}$ & $\begin{array}{l}-0.06 \\
(0.89)\end{array}$ & $\begin{array}{l}0.96^{\star *} \\
(0.02)\end{array}$ & $\begin{array}{l}1.44^{* * *} \\
(0.00)\end{array}$ & $\begin{array}{l}-0.18 \\
(0.72)\end{array}$ & $\begin{array}{l}-0.81 \\
(0.13)\end{array}$ & $\begin{array}{l}-1.11 \\
(0.19)\end{array}$ \\
\hline
\end{tabular}

Notes: $P$ value is reported in parentheses. $* * *, * *$, and $*$ denote significant at $1 \%, 5 \%$, and $10 \%$ level.

In summary, the change of securities price shows significantly positive impact in each model. There should be a strong relationship between abnormal trading volume of illegal insider trading and the change of securities price. It also shows that the quality of concealed important information and whether the insider is sentenced a penalty are the important variables to affect abnormal trading volume.

4.3. The effect of variables to accumulate abnormal returns. In Table 6 , we use the cumulative abnormal returns through the first crime date to the $10^{\text {th }}$ day after first crime date as the dependent variable. We separately regress single independent variable on cumulative abnormal returns in models 1 to 8 . Under the single variable influence, the change of the securities price, the number of defendants, the Penalty dummy, the Fine dummy, the $L a w_{2}$ dummy, and the $L a w_{3}$ dummy are positive related to cumulative abnormal returns. Specifically, the change of the securities price is significantly positive at $1 \%$ level and the Penalty dummy, and the Fine dummy are significantly positive at the 5\% level. Furthermore, the quality of concealed important information is negatively related to cumulative abnormal returns at $1 \%$ level and the Law dummy is negatively related to cumulative abnormal returns.

Table 6. The effect on CAR through the first crime date to the 10th day after

\begin{tabular}{|c|c|c|c|c|c|c|c|c|}
\hline & $\begin{array}{c}\text { Change of } \\
\text { price }\end{array}$ & $\begin{array}{l}\text { Number of } \\
\text { defendants }\end{array}$ & Fine & Penalty & $\begin{array}{c}\text { Good/bad } \\
\text { news }\end{array}$ & Law $_{1}$ & $\mathrm{Law}_{2}$ & $\mathrm{Law}_{3}$ \\
\hline Model 1-8 & $\begin{array}{c}71.73^{\star * \star} \\
(0.00)\end{array}$ & $\begin{array}{c}4.94 \\
(0.18) \\
\end{array}$ & $\begin{array}{c}23.51^{* *} \\
(0.03) \\
\end{array}$ & $\begin{array}{c}24.17^{\star *} \\
(0.02) \\
\end{array}$ & $\begin{array}{l}-49.67^{\star \star \star} \\
(0.00)\end{array}$ & $\begin{array}{r}-15.19 \\
(0.15) \\
\end{array}$ & $\begin{array}{l}16.86 \\
(0.13) \\
\end{array}$ & $\begin{array}{l}19.70 \\
(0.38) \\
\end{array}$ \\
\hline Model 9 & $\begin{array}{c}66.98^{* \star \star} \\
(0.00)\end{array}$ & $\begin{array}{c}-0.19 \\
(0.92)\end{array}$ & $\begin{array}{l}-7.78 \\
(0.29)\end{array}$ & $\begin{array}{c}8.18 \\
(0.24)\end{array}$ & $\begin{array}{c}-6.99 \\
(0.36)\end{array}$ & & & \\
\hline Model 10 & $\begin{array}{c}68.62^{* * *} \\
(0.00)\end{array}$ & $\begin{array}{c}0.16 \\
(0.94)\end{array}$ & $\begin{array}{l}-8.13 \\
(0.31)\end{array}$ & $\begin{array}{c}8.35 \\
(0.25)\end{array}$ & $\begin{array}{l}-6.78 \\
(0.41)\end{array}$ & $\begin{array}{l}-5.47 \\
(0.56)\end{array}$ & $\begin{array}{l}-8.40 \\
(0.39)\end{array}$ & $\begin{array}{l}-7.17 \\
(0.62)\end{array}$ \\
\hline
\end{tabular}

Notes: $P$ value is reported in parentheses. $* * *, * *$, and $*$ denote significant at $1 \%, 5 \%$, and $10 \%$ level. 
In model 9, we regress all the variables except Law dummies on cumulative abnormal returns. It indicates that the impact of the change of securities price on cumulative abnormal return is significantly positive at $1 \%$ level. The Penalty dummy is insignificant positive related to the cumulative abnormal returns. Additionally, the cumulative abnormal return is negatively related to the number of defendants, the Fine dummy and the quality of concealed important information.

In model 10, we add the Law dummies in model 9 to examine whether the variable of relevant laws and regulations has significant impact on cumulative abnormal returns. The impact of the change of the securities price on cumulative abnormal returns shows significant positive at $1 \%$ level. The number of defendants and the Penalty dummy are in significantly positive related to the cumulative abnormal returns. In addition, the cumulative abnormal returns are negatively related to the Fine dummy, the quality of concealed important information. The coefficients of three law dummies are negative and insignificant, indicating that the relevant laws and regulations do not have significant impact on cumulative abnormal returns.

\section{Conclusion}

We examine the illegal insider trading events in Taiwan from 1996 to 2012. We use the following variables which are the change of the securities price, the number of defendants, the penalty and the fine for insider who committed a crime and the quality of concealed important information to examine the determined factor of the illegal insider trading volume and cumulative abnormal returns. In addition, the illegal insider trading is prohibited by the article 157-1 of Securities and Exchange Act in Taiwan, which has been amended three times. We analyze the variation of illegal insider trading volume after the amendment to examine whether it is efficient enough to lower illegal inside trading. The result concludes as following: first, the change of securities price in each model is significantly positively related to the dependent variables, which shows a strong connection to both the illegal insider trading volume and cumulative abnormal returns. Larger change of price tends to create more opportunity for insider to conduct illegal insider trading and more cumulative abnormal returns. Second, it is positive correlation between the quality of concealed important information and the abnormal volume of illegal insider trading whereas it is negative correlation between the quality of concealed important information and cumulative abnormal returns. It indicates when the quality of concealed important information is bad, the insider will trade in stock market to avoid from loss. The stock price goes down and the cumulative abnormal return is negative. Third, the impacts of number of defendants and the relative variables of the amendment on the illegal insider trading volume and cumulative abnormal returns are insignificant. It might be the sample size of the relative variables of the amendment is not enough. Fourth, the relevant laws and regulations do not have significant impact on abnormal trading volume and cumulative abnormal returns.

The above findings have important implications for market regulators. The relevant laws and regulations do not have significant impact on abnormal trading volume and cumulative abnormal returns. Thus, the laws and regulations in punishing the illegal insider traings should be reinforced.

Several possible directions for future research are suggested. First, we aim at analyzing the illegal insider trading events in Taiwan and the independent variables are selected from the insider trading events. Therefore, we suggest that the subsequent researcher might choose the different data section and analyze additional variables related to corporate governance. Second, the sample events are the illegal insider trading prosecuted from 1996 to 2012 in Taiwan, which is inadequate for the sample size and the period of time, especially after the third amendment. Thus, the empirical result might be affected. We suggest that the subsequent researcher could examine longer period of study time and apply a more abundant data to present a comprehensive conclusion.

\section{References}

1. Bhattacharya, U. and Daouk, H. (2002). The World Price of Insider Trading, Journal of Finance, 57, pp. 75-108.

2. Chakravarty, S. and McConnell, J.J. (1997). An Analysis of Prices, Bid/Ask Spreads, and Bid and Ask Depths Surrounding Ivan Boesky's Illegal Trading in Carnation's Stock, Financial Management, 26, pp. 18-34.

3. Cornell, B. and Sirri, E. (1992). The Reaction of Investors and Stock Prices to Insider Trading, Journal of Finance, 47, pp. 1031-1059.

4. Fishe, R.P.H. and Robe, M.A. (2004). The Impact of Illegal Insider Trading in Dealer and Specialist Markets: Evidence from a Natural Experiment, Journal of Financial Economics, 71, pp. 461-488.

5. Frino, A., Satchell, S. and Wong, B. (2009). How Much Does an Illegal Insider Trade? International Review of Finance, 13, pp. 241-263.

6. Guercio, D.D., Odders-White, E.R. and Ready, M.J. (2013). The Effect of SEC Enforcement Intensity on Illegal Insider Trading, Working paper, University of Oregon. 
7. Hou, N.W. (2013). Illegal Insider Trading, Firm Value and Corporate Governance, Working Paper, National Kaohsiung First University of Science and Technology.

8. Hung, C.Y. (2011). The Innovation in Taiwan's Insider Trading Regulation From the Perspective of Legal Interests of England and the U.S. Law, Working Paper, Feng Chia University.

9. Kuang, W.C. and Chiang, Y.C. (2007). Two Godfathers Went to Jail: Who Is the Next? Business Weekly, 1041, pp. 54-62.

10. Meulbroek, L. (1992). An Empirical Analysis of Illegal Insider Trading, Journal of Finance, 47, pp. 1661-1697.

11. Wang, Y.C. and Jan, H.L. (2012). Has Inside Trading Been Improved since Criminal Punishment Was Aggravated? Chaoyang Business and Management Review (special issue), pp. 95-109.

12. Wang, Y.W. (2010). The Study of Corporate Governance on Illegal Insider Trading and Capital Expenditure Efficiency, Working Paper, National Chung Cheng University.

13. Yi, D.Y. (2010). An Analysis of Short Selling, Margin Trading and Bid/Ask Spreads Surrounding Illegal Insider Trading, Working Paper, National Chung Cheng University. 